\title{
SCIENTIFIC REPORTS

\section{OPEN Effects of cultivation management on the winter wheat grain yield and water utilization efficiency}

Received: 11 November 2018

Accepted: 16 August 2019

Published online: 04 September 2019
Yonghua Wang ${ }^{1,2,3}$, Huan Liv ${ }^{1,3}$, Yuan Huang ${ }^{1,3}$, Jinfeng Wang ${ }^{1,3}$, Zhuangzhuang Wang ${ }^{1,3}$, Fengxu Gu ${ }^{1,3}$, Minghua Xin ${ }^{1,3,4}$, Guozhang Kang ${ }^{1,2,3}$, Wei Feng ${ }^{1,2,3}$ \& Tiancai Guo ${ }^{1,2,3}$

The growth of winter wheat consumes a substantial amounts of water, and precipitation in most years cannot meet the water demand for the normal growth of winter wheat. The unsuitable irrigation strategies waste a large number of water resource, and the low water use efficiency has become the main factor limiting wheat yields. This research explored the effects of different cultivation managements on water consumption characteristics, water utilization efficiency, and grain yields of winter wheat. A field experiment, in which 4 cultivation managements including traditional cultivation management (T1), optimized cultivation management compared with T1 (T2), super high-yield cultivation management (T3) and optimized cultivation management compared with T3 (T4), was conducted during 2008-2010 to measure the above parameters. The results showed that different cultivation managements had significant effects on the total water consumption amounts and water source compositions. Total water consumption amounts in T1 and T3 managements were significantly higher than that in T2 and T4 managements, possibly from irrigation water. T2 and T4 managements remarkably increased the uptake and utilization of soil storage water and precipitation amounts. T3 and T1 managements increased and decreased water consumption in upper $(0-40 \mathrm{~cm})$ and lower $(60-100 \mathrm{~cm})$ soil layers, respectively, while effectively increased the consumption of storage water in middle and lower soil layers $(60-100 \mathrm{~cm})$ and yield water use efficiency $\left(W \mathrm{E}_{\mathrm{Y}}\right)$, precipitation water use efficiency $\left(W U E_{p}\right)$, soil water use efficiency $\left(W U E_{S}\right)$, irrigation water use efficiency $\left(W U E_{1}\right)$, and irrigation efficiency (IE) in T4 and T2 managements were higher than those in T3 and T1, respectively. Total water consumption amounts markedly raised in T1 and T3 managements, whereas their soil storage water amounts utilization declined. T2 and T4 managements reduced irrigation water amounts and optimized the water and fertilizer supplies, resulting in significant increase in WUE ${ }_{s}$ and $W_{U E}$. Collectively, our results suggest that synergetic improving the water uptake and utilization of irrigation water and soil storage water can be the primary means to increase the grain yields and WUE.

Huang-Huai-Hai Plain region, in which mainly occurs a monsoon climate of medium latitude with sufficient heating, lighting conditions and convenient irrigation conditions, is the region with the most suitable ecological conditions for winter wheat growth, and wheat sowing area and total wheat output in this region rank first in China $^{1}$. In this region, $70-80 \%$ of precipitation occurs from July to September every year, however, the remaining appears other months, a stage of wheat growth and development, does not satisfy the water requirement for wheat, and water shortage has become the main factor limiting wheat yields in this region ${ }^{2,3}$. Therefore, irrigation water is an important guarantee for high yields of winter wheat, whereas the current irrigation systems, e.g. unsuitable irrigation periods and amounts, waste a large amount of water resource ${ }^{4}$, and to improve WUE of irrigation water and precipitation has become an urgent task in this region. It has been reported that soil water content is an important factor affecting the water consumption of wheat and the soil water efficiencies in different soil layers, what's more, irrigation effectively changes the water content in the soil profiles, and affects the water uptake

${ }^{1}$ National Engineering Research Centre for Wheat, \#15 Longzihu College District, Zhengzhou, Henan, 450046, PR China. 'Synergetic Innovation Center of Henan Grain Crops, \#15 Longzihu College District, Zhengzhou, Henan, 450046, PR China. ${ }^{3}$ Agronomy College of Henan Agricultural University, \#15 Longzihu College District, Zhengzhou,

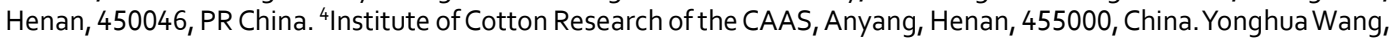
Huan Liu, Yuan Huang and Tiancai Guo contributed equally. Correspondence and requests for materials should be addressed toY.W. (email: wangyonghua88@126.com) orT.G. (email: gtcwheat@henau.edu.cn) 


\begin{tabular}{|c|c|c|c|c|c|c|c|c|c|c|}
\hline \multirow[b]{2}{*}{$\begin{array}{l}\text { Meteorological } \\
\text { factors }\end{array}$} & \multirow[b]{2}{*}{ Year } & \multicolumn{9}{|l|}{ Growth season } \\
\hline & & October & November & December & January & February & March & April & May & $\begin{array}{l}\text { First } 10 \text { days } \\
\text { in June }\end{array}$ \\
\hline \multirow{2}{*}{$\begin{array}{l}\text { Average } \\
\text { temperature }\left({ }^{\circ} \mathrm{C}\right)\end{array}$} & 2008-2009 & $16.58(+1.35)$ & $9.43(+1.36)$ & $2.64(+0.68)$ & $-0.17(-0.37)$ & $5.36(+2.56)$ & $9.23(+0.91)$ & $15.86(+0.75)$ & $20.73(-0.02)$ & $25.75(-0.70)$ \\
\hline & $2009-2010$ & $17.44(+2.14)$ & $4.90(-3.17)$ & $1.92(-0.14)$ & $0.03(-0.17)$ & $3.16(+0.43)$ & $8.04(-0.25)$ & $13.28(-1.83)$ & $20.99(+0.26)$ & $22.46(-2.59)$ \\
\hline \multirow{2}{*}{$\begin{array}{l}\text { Precipitation } \\
(\mathrm{mm})\end{array}$} & $2008-2009$ & $16.60(-23.20)$ & $15.20(-5.50)$ & $0.20(-7.80)$ & $0.00(-7.80)$ & $30.40(+19.70)$ & $32.40(+10.40)$ & $30.30(+3.00)$ & $83.90(+37.20)$ & $17.40(+2.10)$ \\
\hline & 2009-2010 & $13.10(-26.70)$ & $39.40(+18.70)$ & $1.40(-6.60)$ & $0.10(-7.70)$ & $8.80(-1.90)$ & $9.50(-12.50)$ & $47.40(+14.10)$ & $25.90(-20.80)$ & $22.60(+7.30)$ \\
\hline \multirow{2}{*}{$\begin{array}{l}\text { Duration of } \\
\text { sunshine (h) }\end{array}$} & 2008-2009 & $168.70(-11.60)$ & $161.50(+6.90)$ & $173.60(+18.50)$ & $152.40(+2.10)$ & $73.90(-76.20)$ & $172.40(-10.40)$ & $213.80(+10.40)$ & $208.90(-31.40)$ & $85.90(+8.00)$ \\
\hline & $2009-2010$ & $146.30(-34.00)$ & $128.10(-32.50)$ & $145.10(-10.00)$ & $122.80(-33.50)$ & $72.70(-77.40)$ & $145.60(-37.20)$ & $201.30(-8.10)$ & $232.80(-7.50)$ & $48.00(-29.90)$ \\
\hline
\end{tabular}

Table 1. Meteorological parameters at two successive wheat growth seasons from October 2008 to June 2010 at our experimental region. Note: Data in the brackets represent the difference in meteorological factors between the year and a normal year (1962-2006).

\begin{tabular}{|c|c|c|c|c|c|c|c|c|}
\hline \multirow[b]{2}{*}{ Year } & \multirow[b]{2}{*}{ Managements } & \multirow{2}{*}{$\begin{array}{l}\text { Amounts of total } \\
\text { water consumption } \\
(\mathrm{mm})\end{array}$} & \multirow{2}{*}{$\begin{array}{l}\text { Amounts of } \\
\text { precipitation } \\
\text { water }(\mathbf{m m})\end{array}$} & \multirow{2}{*}{$\begin{array}{l}\text { Amounts of } \\
\text { irrigation water } \\
(\mathrm{mm})\end{array}$} & \multirow{2}{*}{$\begin{array}{l}\text { Amounts of soil } \\
\text { water consumption } \\
(\mathrm{mm})\end{array}$} & \multicolumn{3}{|c|}{ Ratio to total water consumption (\%) } \\
\hline & & & & & & Precipitation & Irrigation & Soil water \\
\hline \multirow{4}{*}{$2008-2009$} & $\mathrm{~T} 1$ & $507.5 \mathrm{bB}$ & 168.2 & 270.0 & $69.3 \mathrm{cC}$ & $33.1 \mathrm{cC}$ & $53.2 \mathrm{aA}$ & $13.6 \mathrm{~dB}$ \\
\hline & $\mathrm{T} 2$ & $482.9 \mathrm{cC}$ & 168.2 & 240.0 & $74.7 \mathrm{cC}$ & $34.8 \mathrm{bB}$ & $49.7 \mathrm{bB}$ & $15.5 \mathrm{cB}$ \\
\hline & T3 & $536.1 \mathrm{aA}$ & 168.2 & 240.0 & $127.9 \mathrm{aA}$ & $31.4 \mathrm{dD}$ & $44.8 \mathrm{cC}$ & $23.8 \mathrm{aA}$ \\
\hline & $\mathrm{T} 4$ & $447.1 \mathrm{dD}$ & 168.2 & 180.0 & $98.9 \mathrm{bB}$ & $37.6 \mathrm{aA}$ & $40.3 \mathrm{dD}$ & $22.1 \mathrm{bA}$ \\
\hline \multirow{4}{*}{$2009-2010$} & $\mathrm{~T} 1$ & $545.9 \mathrm{bB}$ & 226.4 & 270.0 & $49.5 \mathrm{bB}$ & $41.5 \mathrm{cC}$ & $49.5 \mathrm{aA}$ & $9.1 \mathrm{cBC}$ \\
\hline & $\mathrm{T} 2$ & $509.4 \mathrm{cC}$ & 226.4 & 240.0 & $43.0 \mathrm{cB}$ & $44.4 \mathrm{bB}$ & $47.1 \mathrm{bB}$ & $8.4 \mathrm{cC}$ \\
\hline & T3 & $567.0 \mathrm{aA}$ & 226.4 & 240.0 & $100.6 \mathrm{aA}$ & $39.9 \mathrm{dD}$ & $42.3 \mathrm{cC}$ & $17.7 \mathrm{aA}$ \\
\hline & $\mathrm{T} 4$ & $452.3 \mathrm{dD}$ & 226.4 & 180.0 & $45.9 \mathrm{bcB}$ & $50.1 \mathrm{aA}$ & $39.8 \mathrm{dD}$ & $10.1 \mathrm{bB}$ \\
\hline
\end{tabular}

Table 2. Total water consumption and water composition in four managements. Note: The experimental data were evaluated using analysis of variance (ANOVA) and correlation analysis with SPSS 16.0, and multiple comparisons were conducted for significant effects using the least significant difference (LSD) test at $\alpha=0.05$ and $\alpha=0.01$.

and utilization of wheat, whereas the excessive use and severe deficit of soil water obviously decrease WUE $\mathrm{W}_{\mathrm{S}}$ of winter wheat ${ }^{5-9}$. Conventional tillage in successive years has been found to harden and tighten the soil layers below $30 \mathrm{~cm}$, leading to the formation of the bottom layer of plough, the enhancement of the soil permeability and porosity, and reduction of soil storage water capacity. This is unsuitable to the root growth and the water absorption and utilization, resulting in a great decline in the crop yields and WUE ${ }^{10}$. Deep ploughing can promote the crop growth and increase the grain yields through deepening the plough layer, broking the hard plough layer, and improving the soil layer structures at $30-40 \mathrm{~cm}$, the soil porosity ${ }^{11}$, the soil water infiltration capacity and storage water capacity, and the soil storage water capacity and WUE ${ }^{12}$. Zhang and his colleagues have found that both irrigation periods and amounts significantly affect the wheat grain yields and WUE ${ }^{13}$. Even if the total irrigation amounts are same, different irrigation methods and irrigation water distributions during different growth stages also have significant effects on the wheat yields and WUE ${ }^{14,15}$. Water consumption and WUE of winter wheat are remarkably changed by other factors, such as wheat varieties ${ }^{16,17}$, tillage managements ${ }^{18-20}$, irrigation systems (irrigation amounts, periods and frequencies) $)^{21-23}$, and fertilizers ${ }^{24,25}$. Totally, these previous studies focused on the effects of single or double factors and their interactions on WUE of winter wheat. To our knowledge, however, the effects of comprehensive agronomic managements including sowing, water and fertilizer management, etc. on the grain yields and water use of winter wheat remain unclear. In the present study, we conducted a field trait, in which four combined cultivation managements including tillage, row spacing configuration, water and fertilizer inputs and planting densities, was set up to aim at their effects on the water consumption characteristics, WUE and grain yields of winter wheat. And we propose a hypothesis that combination of the above mentioned agronomic managements could effectively improve the grain yields and water use of winter wheat.

\section{Results}

Total water consumption and water composition of different sources of winter wheat. This experiment was conducted in two successive seasons of wheat growth in 2008.10.01-2009.06.10 and 2009.10.012010.06.10, in which appeared serious drought and low temperature, respectively (Table 1). The four cultivation managements had remarkable effects on the total water consumption amounts and the water source compositions, and the differences were significant among four cultivation managements $(P<0.05$ or $P<0.01)$ (Table 2). In two wheat growth seasons (2008-2009 and 2009-2010), amounts of the total water consumption among the four cultivation managements showed similar patterns: T3 $>\mathrm{T} 1>\mathrm{T} 2>\mathrm{T} 4$. Compared with T1, T2, and T4, average amounts of the total water consumption in T3 during the two seasons increased by $4.8 \%, 11.2 \%$, and $22.6 \%$, respectively (Table 2). Compared with $\mathrm{T} 1$ and $\mathrm{T} 4$, however, this parameter in T2 significantly decreased by $5.8 \%$ and $18.4 \%$, respectively. There were different profiles on amounts of the soil water consumption between T1 


\begin{tabular}{|c|c|c|c|c|c|c|c|c|c|c|c|c|c|c|c|c|}
\hline \multirow[b]{2}{*}{ Year } & \multirow[b]{2}{*}{ Managements } & \multicolumn{3}{|c|}{ Emergence to wintering } & \multicolumn{3}{|c|}{$\begin{array}{l}\text { Wintering to growth } \\
\text { resuming }\end{array}$} & \multicolumn{3}{|c|}{ Growth resuming to jointing } & \multicolumn{3}{|c|}{ Jointing to anthesis } & \multicolumn{3}{|c|}{ Anthesis to maturity } \\
\hline & & $\begin{array}{l}\text { WC } \\
(\mathrm{mm})\end{array}$ & $\begin{array}{l}\text { DWC } \\
(\mathbf{m m})\end{array}$ & $\begin{array}{l}\text { WCC } \\
(\%)\end{array}$ & $\begin{array}{l}\text { WC } \\
(\mathrm{mm})\end{array}$ & $\begin{array}{l}\text { DWC } \\
(\mathrm{mm})\end{array}$ & $\begin{array}{l}\text { WCC } \\
(\%)\end{array}$ & $\begin{array}{l}\text { WC } \\
(\mathrm{mm})\end{array}$ & $\begin{array}{l}\text { DWC } \\
(\mathrm{mm})\end{array}$ & WCC (\%) & $\begin{array}{l}\text { WC } \\
(\mathrm{mm})\end{array}$ & $\begin{array}{l}\text { DWC } \\
(\mathrm{mm})\end{array}$ & $\operatorname{WCC}(\%)$ & $\begin{array}{l}\text { WC } \\
(\mathrm{mm})\end{array}$ & $\begin{array}{l}\text { DWC } \\
(\mathrm{mm})\end{array}$ & $\begin{array}{l}\text { WCC } \\
(\%)\end{array}$ \\
\hline \multirow{4}{*}{$2008-2009$} & $\mathrm{~T} 1$ & $102.4 \mathrm{bB}$ & $1.6 \mathrm{bB}$ & $20.2 \mathrm{aA}$ & $52.1 \mathrm{aA}$ & $0.8 \mathrm{aA}$ & $10.3 \mathrm{bB}$ & $73.0 \mathrm{cC}$ & $2.1 \mathrm{cC}$ & $14.4 \mathrm{bB}$ & $128.4 \mathrm{aA}$ & $4.0 \mathrm{aA}$ & $25.3 \mathrm{aA}$ & $151.5 \mathrm{aAB}$ & $4.0 \mathrm{aAB}$ & $29.8 \mathrm{aA}$ \\
\hline & $\mathrm{T} 2$ & $99.6 \mathrm{bB}$ & $1.5 \mathrm{bB}$ & $20.6 \mathrm{aA}$ & $49.8 \mathrm{aA}$ & $0.8 \mathrm{aA}$ & $10.3 \mathrm{bB}$ & $71.9 \mathrm{cC}$ & $2.1 \mathrm{cC}$ & $14.9 \mathrm{bB}$ & $117.0 \mathrm{bAB}$ & $3.7 \mathrm{bBC}$ & $24.2 \mathrm{abAB}$ & $144.6 \mathrm{bB}$ & $3.8 \mathrm{bB}$ & $29.9 \mathrm{aA}$ \\
\hline & $\mathrm{T} 3$ & $111.4 \mathrm{aA}$ & $1.7 \mathrm{aA}$ & $20.8 \mathrm{aA}$ & $51.4 \mathrm{aA}$ & $0.8 \mathrm{aA}$ & $9.6 \mathrm{cC}$ & $91.0 \mathrm{aA}$ & $2.6 \mathrm{aA}$ & $17.0 \mathrm{aA}$ & $125.0 \mathrm{abA}$ & $3.9 \mathrm{aAB}$ & $23.3 \mathrm{bB}$ & $157.3 \mathrm{aA}$ & $4.1 \mathrm{aA}$ & $29.4 \mathrm{aA}$ \\
\hline & $\mathrm{T} 4$ & $92.7 \mathrm{cC}$ & $1.4 \mathrm{cC}$ & $20.7 \mathrm{aA}$ & $51.5 \mathrm{aA}$ & $0.8 \mathrm{aA}$ & $11.5 \mathrm{aA}$ & $78.2 \mathrm{bB}$ & $2.2 \mathrm{bB}$ & $17.5 \mathrm{aA}$ & $107.1 \mathrm{cB}$ & $3.3 \mathrm{cC}$ & $24.0 \mathrm{abAB}$ & $117.6 \mathrm{cC}$ & $3.1 \mathrm{cC}$ & $26.3 \mathrm{bB}$ \\
\hline \multirow{4}{*}{$2009-2010$} & $\mathrm{~T} 1$ & $86.9 \mathrm{abAB}$ & $1.3 \mathrm{aAB}$ & $15.9 \mathrm{bB}$ & $48.8 \mathrm{aA}$ & $0.8 \mathrm{aA}$ & $8.9 \mathrm{bB}$ & $74.7 \mathrm{bAB}$ & $2.8 \mathrm{bB}$ & $13.7 \mathrm{cC}$ & $162.0 \mathrm{aA}$ & $3.9 \mathrm{aA}$ & $29.7 \mathrm{abAB}$ & $173.4 \mathrm{bB}$ & $4.4 \mathrm{bB}$ & $31.8 \mathrm{bA}$ \\
\hline & $\mathrm{T} 2$ & $79.7 \mathrm{cC}$ & $1.2 \mathrm{bB}$ & $15.6 \mathrm{bB}$ & $39.5 \mathrm{cC}$ & $0.6 \mathrm{cC}$ & $7.8 \mathrm{cC}$ & $71.9 \mathrm{cC}$ & $2.7 \mathrm{cC}$ & $14.1 \mathrm{bcBC}$ & $151.2 \mathrm{bAB}$ & $3.6 \mathrm{bAB}$ & $29.7 \mathrm{abAB}$ & $167.1 \mathrm{bB}$ & $4.3 \mathrm{bB}$ & $32.8 \mathrm{abA}$ \\
\hline & $\mathrm{T} 3$ & $89.1 \mathrm{aA}$ & $1.3 \mathrm{aA}$ & $15.7 \mathrm{bB}$ & $43.1 \mathrm{bB}$ & $0.7 \mathrm{bB}$ & $7.6 \mathrm{cC}$ & $82.2 \mathrm{aA}$ & $3.0 \mathrm{aA}$ & $14.5 \mathrm{bB}$ & $158.7 \mathrm{abA}$ & $3.8 \mathrm{aA}$ & $28.0 \mathrm{bB}$ & $193.9 \mathrm{aA}$ & $5.0 \mathrm{aA}$ & $34.2 \mathrm{aA}$ \\
\hline & $\mathrm{T} 4$ & $85.4 \mathrm{bB}$ & $1.2 \mathrm{aAB}$ & $18.9 \mathrm{aA}$ & $42.4 \mathrm{bB}$ & $0.7 \mathrm{bB}$ & $9.4 \mathrm{aA}$ & $76.7 \mathrm{bB}$ & $2.8 \mathrm{bB}$ & $16.9 \mathrm{aA}$ & $141.7 \mathrm{cC}$ & $3.4 \mathrm{cB}$ & $31.3 \mathrm{aA}$ & $106.1 \mathrm{cC}$ & $2.7 \mathrm{cC}$ & $23.5 \mathrm{cB}$ \\
\hline
\end{tabular}

Table 3. Water consumption characteristics in different wheat growth stages. Notes: WC, water consumption; DWC, daily water consumption; WCC, water consumption coefficient. The experimental data were evaluated using analysis of variance (ANOVA) and correlation analysis with SPSS 16.0, and multiple comparisons were conducted for significant effects using the least significant difference (LSD) test at $\alpha=0.05$ and $\alpha=0.01$.

and T2, insignificant and significant differences in the drought year (2008-2009) and the low-temperature year (2009-2010), respectively. Compared with T3, amounts of the soil water consumption in T4 decreased significantly by average $38.6 \%$ in two seasons (Table 2 ).

Because water consumption sources in crops are composed of irrigation water, precipitation, and soil storage water, we compared their proportions in the total water consumption amounts in our experiment. Our data showed that the former two components accounted for higher proportions $(76.2 \% \sim 91.6 \%)$ of the total water consumption amounts in the wheat field, whereas that of soil storage water was merely $8.4 \% \sim 23.8 \%$. In both the dry year and the low-temperature year, the proportion of precipitation in T4 was $6.5 \%, 4.2 \%$ and $8.2 \%$ higher than $\mathrm{T} 1, \mathrm{~T} 2$ and T3, respectively. Additionally, proportion of precipitation in T2 was $6.2 \%$ higher than T1, and T4 was $23.0 \%$ higher than T3 (Table 2). The proportion of irrigation water of the total water consumption in T1 was $2.9 \%$, $7.8 \%$, and $11.3 \%$ higher than those in T2, T3 and T4, respectively (Table 2). The highest proportion of soil storage water appeared in T3, 9.4\%, 8.8\% and 4.7\% higher than T1, T2 and T4, respectively (Table 2).

Water consumption characteristics in different growth stages of winter wheat. Different cultivation managements significantly changed the water consumption, daily water consumption and water consumption coefficient at different growth stages of wheat plants (Table 3). In two tested years, water consumption amounts was greatest at the middle (from jointing to anthesis, JTA) and late (from anthesis to maturity, ATM) growth stages of wheat plants under all managements, while least at the stage of wintering to resuming (WTR). After wintering, the daily water consumption and water consumption coefficient gradually increased in four managements with the proceeded growth stages (Table 3). Compared with the WTR stage, water consumption at the JTA and ATM stages increased by from 1.1- to 2.8-fold and 1.3- to 3.5-fold, respectively, and the water consumption coefficient increased by from $12.4 \%$ to $22.0 \%$ and $14.8 \%$ to $26.6 \%$, respectively. Comparison among four managements indicated that the highest water consumption and daily water consumption at each growth stage occurred in T3 and T1 and differences among four managements increased gradually with the proceeded growth stages. Water consumption and daily water consumption at JTA stage in T1 management were higher than T2, T3, and T4 by $8.5 \%, 2.4 \%$, and $17.1 \%$, respectively (Table 3 ). These two parameters at ATM stage in T3 management were higher than $\mathrm{T} 1, \mathrm{~T} 2$, and $\mathrm{T} 4$ by $7.8 \%, 12.4 \%$, and $58.3 \%$, respectively (Table 3 ). From wintering to anthesis (WTA) stages, the water consumption coefficient in T4 management was higher than that of T3, but significantly declined at the ATM stage by $6.9 \%$. However, there was insignificant differences in the water consumption coefficient between T1 and T2 managements at all stages, except for JTA stages.

The relationship between the grain yields and water consumption amounts at each growth stage of winter wheat differed among four managements (Fig. 1). There was a positive correlation between the grain yields and water consumption amounts at ETW and RTJ stages, while negative correlation occurred at WTR, JTA and ATM stages with $\mathrm{R}^{2} \mathrm{JTA}>\mathrm{R}^{2} \mathrm{ATM}>\mathrm{R}^{2} \mathrm{WTR}$ (Fig. 1). This finding demonstrated that reducing water consumption after the jointing stage could be used as an efficient mean to improve wheat yields.

Water consumption of the different soil layers. Among the four cultivation managements, the highest soil water consumption amounts appeared at the $40-60 \mathrm{~cm}$ soil layer and at this layer, the proportion was up to $29.5 \%-34.4 \%$ (Fig. 2). Soil water consumption amounts at $80-100 \mathrm{~cm}$ layer, however, was lower and its proportion was only from $5.6 \%$ to $11.2 \%$ (Fig. 2). Soil water consumption amounts at $0-20 \mathrm{~cm}$ and $20-40 \mathrm{~cm}$ layers in T1 and T3 were significantly higher than those in T2 and T4, respectively, whereas this parameter below $60 \mathrm{~cm}$ soil layer decreased significantly (Fig. 2). Water consumption amounts above $40 \mathrm{~cm}$ soil layer in T2 management was significantly lower than T1 management, and T4 was also lower than T3 management (Fig. 2). Average reduction rates of water consumption amounts in T2 management declined by $28.5 \%$ compared to that of T1, with T4 compared to T3 by $47.3 \%$ (Fig. 2). Compared to T1, soil water consumption amounts at $60-80 \mathrm{~cm}$ and $80-100 \mathrm{~cm}$ soil layers in T2 management increased by $57.1 \%$ and $54.3 \%$, respectively (Fig. 2). This parameter at $80-100 \mathrm{~cm}$ soil layer in T3 and T4 managements exhibited differential profiles during the two growth seasons. In the dry year 


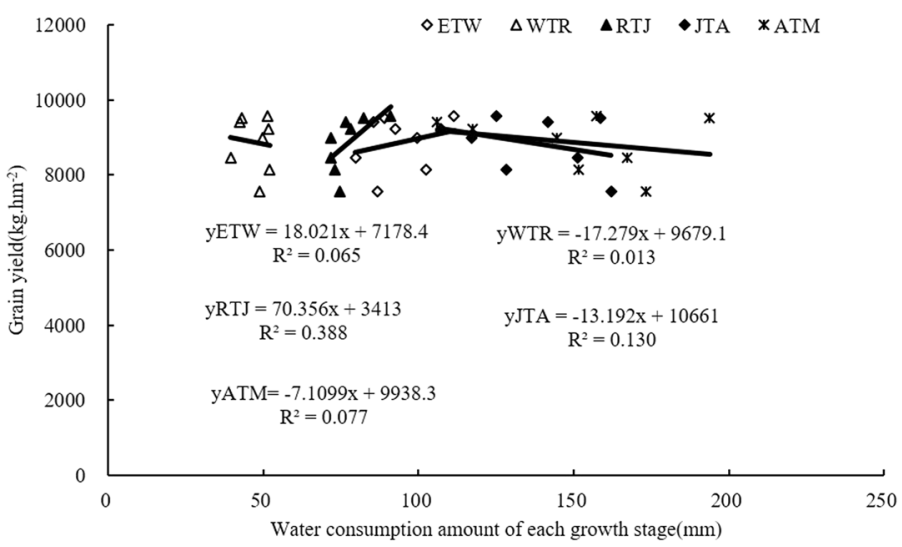

Relationships between the grain yields and water consumption amounts at each growth stage.

Note: ETW, emergence to wintering; WTR, wintering to resuming growth; RTJ, resuming growth to jointing; JTA, jointing to anthesis; ATM, anthesis to maturity. The correlation analysis was conducted between means across 2008 to $2010, \mathrm{n}=8, \mathrm{r} 0.05=0.707, \mathrm{r} 0.01=0.834$.

Figure 1. Relationships between the grain yields and water consumption amounts at each growth stage.

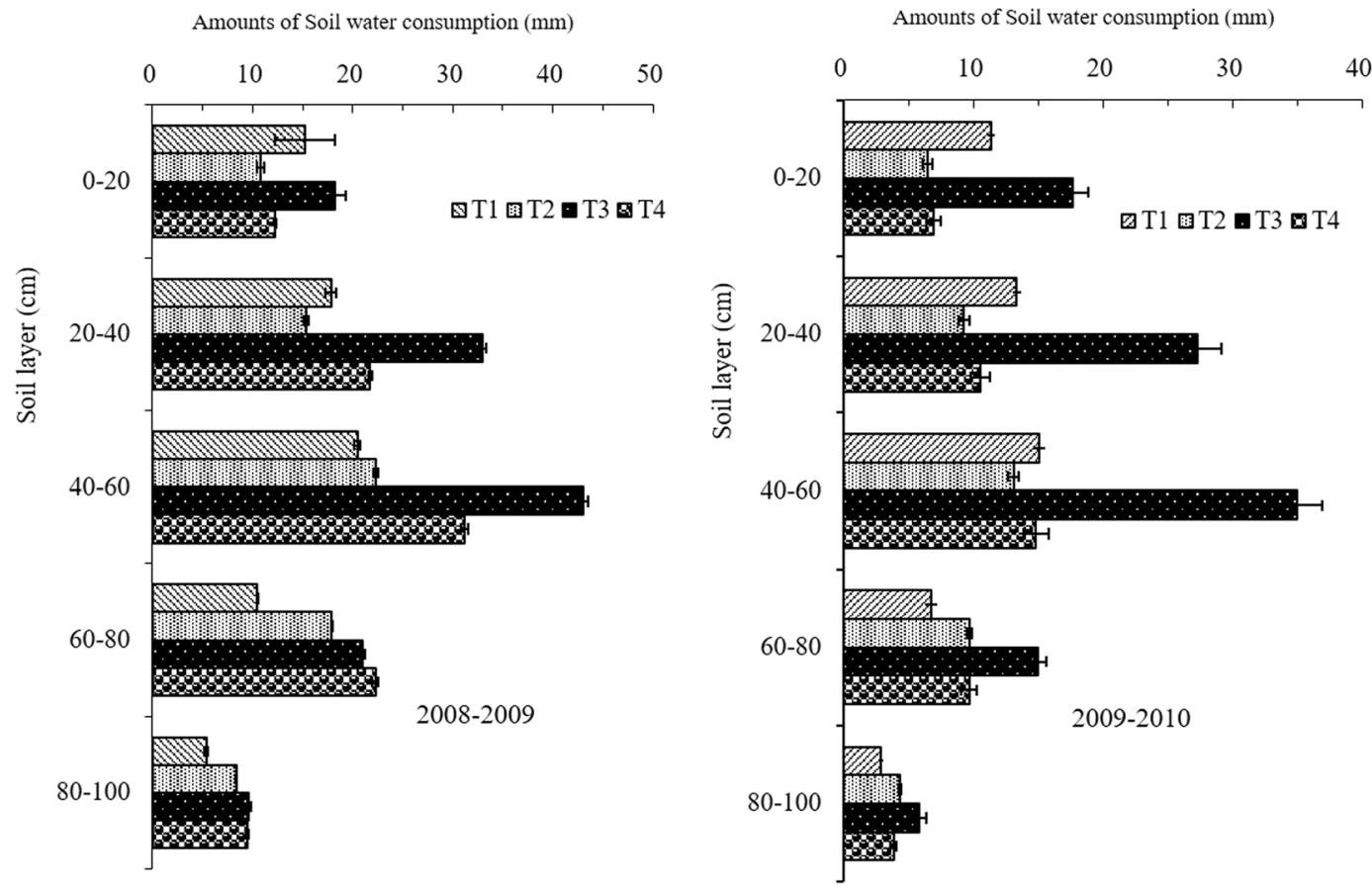

The water consumption at different soil layers among four different managements.

Figure 2. The water consumption at different soil layers among four different managements.

(2008-2009), soil water consumption amounts at $80-100 \mathrm{~cm}$ soil layer in T4 were higher than T3 by $6.1 \%$. In the low-temperature year (2009-2010), however, the former were lower than the latter by $35.1 \%$. These suggested that T1 and T3 managements absorbed more and less water from the upper and the lower soil layers, respectively, possibly from root hydrotropism. In T1 and T3 managements, irrigated water mainly was storaged at the upper soil layer, leading to appearance of roots mainly at this soil layer. The optimized managements (T2 and T4) with reduced irrigation amounts and optimized irrigation periods helped promote the roots to grow at middle and lower soil layers and enhance the absorption and utilization at these two soil layers (Fig. 2).

Yield and water use efficiency. Different cultivation managements had differential regulatory effects on the grain yields and WUE (Table 4). In two successive tested years, the grain yields, $\mathrm{WUE}_{\mathrm{Y}}, \mathrm{WUE}_{\mathrm{P}}, \mathrm{WUE}_{\mathrm{I}}$ and IE parameters in T1 management were least among all managements in two tested years, and decreased by $\geq 2.3 \%$, $13.8 \%, 10.0 \%, 20.0 \%$ and $54.2 \%$ lower than other three treatments, respectively (Table 4). Compared with T1, $\mathrm{WUE}_{\mathrm{Y}}, \mathrm{WUE}_{\mathrm{S}}$, WUE $\mathrm{P}, \mathrm{WUE}_{\mathrm{I}}$ and IE in T2 remarkably increased by $18.0 \%, 15.6 \%, 11.1 \%, 25.0 \%$, and $118.04 \%$, 


\begin{tabular}{|c|c|c|c|c|c|c|c|}
\hline Year & Managements & GY $\left(\mathbf{k g} \cdot \mathrm{hm}^{-2}\right)$ & $\mathrm{WUE}_{\mathrm{Y}} \mathrm{kg} \cdot \mathrm{hm}^{-2} \cdot \mathrm{mm}^{-1}$ & $\mathrm{WUE}_{\mathrm{S}} \mathrm{kg} \cdot \mathrm{hm}^{-2} \cdot \mathrm{mm}^{-1}$ & WUE $_{\mathrm{p}} \mathrm{kg} \cdot \mathrm{hm}^{-2} \cdot \mathrm{mm}^{-1}$ & $\mathrm{WUE}_{\mathrm{I}} \mathrm{kg} \cdot \mathrm{hm}^{-2} \cdot \mathrm{mm}^{-1}$ & IE kg.hm ${ }^{-2} \cdot \mathrm{mm}^{-1}$ \\
\hline \multirow{4}{*}{$2008-2009$} & $\mathrm{~T} 1$ & $8136.5 \mathrm{cC}$ & $16.0 \mathrm{dC}$ & $117.6 \mathrm{aA}$ & $48.4 \mathrm{cC}$ & $30.1 \mathrm{dD}$ & $3.3 \mathrm{cC}$ \\
\hline & $\mathrm{T} 2$ & 8997.4 bB & $18.6 \mathrm{bB}$ & $120.6 \mathrm{aA}$ & $53.5 \mathrm{bB}$ & $37.5 \mathrm{cC}$ & $7.3 \mathrm{bB}$ \\
\hline & T3 & $9573.79 \mathrm{aA}$ & $17.9 \mathrm{cB}$ & $75.2 \mathrm{cC}$ & $56.9 \mathrm{aA}$ & $39.9 \mathrm{bB}$ & $9.7 \mathrm{aA}$ \\
\hline & $\mathrm{T} 4$ & $9229.79 \mathrm{bAB}$ & $20.6 \mathrm{aA}$ & $93.7 \mathrm{bB}$ & $54.9 \mathrm{aAB}$ & $51.3 \mathrm{aA}$ & $11.0 \mathrm{aA}$ \\
\hline \multirow{4}{*}{ 2009-2010 } & $\mathrm{T} 1$ & $7566.18 \mathrm{cC}$ & $13.9 \mathrm{cC}$ & $153.0 \mathrm{bB}$ & $33.4 \mathrm{cC}$ & $28.0 \mathrm{dD}$ & $3.6 \mathrm{dD}$ \\
\hline & $\mathrm{T} 2$ & $8452.56 \mathrm{bB}$ & $16.6 \mathrm{bB}$ & $196.8 \mathrm{aA}$ & $37.3 \mathrm{bB}$ & $35.2 \mathrm{cC}$ & $7.7 \mathrm{cC}$ \\
\hline & $\mathrm{T} 3$ & $9519.90 \mathrm{aA}$ & $16.8 \mathrm{bB}$ & $94.8 \mathrm{cC}$ & $42.0 \mathrm{aA}$ & $39.7 \mathrm{bB}$ & $12.2 \mathrm{bB}$ \\
\hline & $\mathrm{T} 4$ & $9416.04 \mathrm{aA}$ & $20.8 \mathrm{aA}$ & $206.0 \mathrm{aA}$ & $41.6 \mathrm{aA}$ & $52.3 \mathrm{aA}$ & $15.7 \mathrm{aA}$ \\
\hline
\end{tabular}

Table 4. Yield and water use efficiency. Notes: GY, grain yield; $W_{U E}$, yield water use efficiency; $W_{E_{S}}$, soil water use efficiency; $\mathrm{WUE}_{\mathrm{p}}$, precipitation water use efficiency; $\mathrm{WUE}_{\mathrm{I}}$, irrigation water use efficiency; IE, irrigation effectiveness. The experimental data were evaluated using analysis of variance (ANOVA) and correlation analysis with SPSS 16.0, and multiple comparisons were conducted for significant effects using the least significant difference (LSD) test at $\alpha=0.05$ and $\alpha=0.01$.

\begin{tabular}{|c|c|c|c|c|c|c|c|}
\hline Year & Parameters & GY & WUE $_{\mathbf{Y}}$ & WUE $_{\mathrm{s}}$ & $\mathrm{WUE}_{\mathrm{P}}$ & WUE $_{I}$ & IE \\
\hline \multirow{6}{*}{ 2008-2009 } & GY & 1.000 & & & & & \\
\hline & $\mathrm{WUE}_{\mathrm{Y}}$ & $0.645^{* * *}$ & 1.000 & & & & \\
\hline & $\mathrm{WUE}_{\mathrm{S}}$ & $-0.708^{* *}$ & -0.243 & 1.000 & & & \\
\hline & WUE $_{\mathrm{p}}$ & $1.000^{* *}$ & $0.646^{* *}$ & $-0.708^{* *}$ & 1.000 & & \\
\hline & WUE $_{I}$ & $0.679^{* *}$ & $0.946^{* *}$ & -0.494 & $0.680^{* *}$ & 1.000 & \\
\hline & IE & $0.918^{* *}$ & $0.854^{* *}$ & $-0.669^{* *}$ & $0.918^{* *}$ & $0.910^{* *}$ & 1.000 \\
\hline \multirow{6}{*}{ 2009-2010 } & GY & 1.000 & & & & & \\
\hline & $\mathrm{WUE}_{\mathrm{Y}}$ & $0.785^{* *}$ & 1.000 & & & & \\
\hline & $\mathrm{WUE}_{\mathrm{S}}$ & -0.154 & 0.452 & 1.000 & & & \\
\hline & $\mathrm{WUE}_{\mathrm{p}}$ & $1.000^{* * *}$ & $0.783^{* * *}$ & -0.156 & 1.000 & & \\
\hline & WUE $_{I}$ & $0.836^{* *}$ & $0.987^{* *}$ & 0.322 & $0.835^{* *}$ & 1.000 & \\
\hline & IE & $0.940^{* * *}$ & $0.926^{* *}$ & 0.105 & $0.939^{* *}$ & $0.962^{* *}$ & 1.000 \\
\hline
\end{tabular}

Table 5. Relationships between grain yields and water use efficiency. Notes: GY, grain yield; WUE $E_{Y}$ yield water use efficiency; $W_{U E}$, soil water use efficiency; $W_{U E}$, precipitation water use efficiency; $W_{U E}$, irrigation water use efficiency; IE, irrigation effectiveness. ns indicates non-significant. * and ** indicate significant differences at the p-levels of 0.05 and 0.01 , respectively. $\mathrm{n}=6 . \mathrm{P}(\mathrm{t} 0.05)=2.571, \mathrm{P}(\mathrm{t} 0.01)=4.032$.

respectively (Table 4). Compared with T3, WUE $, \mathrm{WUE}_{\mathrm{S}}, \mathrm{WUE}_{\mathrm{I}}$ and IE in T4 also increased by 19.8\%, 70.9\%, $30.2 \%$ and $21.1 \%$, respectively (Table 4 ). However, there was insignificant difference in WUE $\mathrm{W}_{\mathrm{P}}$ between T3 and

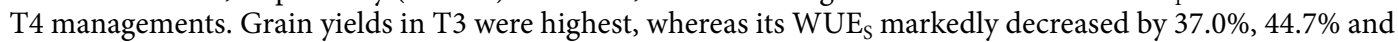
$36.9 \%$ in comparison to T1, T2 and T4, respectively (Table 4). These suggested that T3 management primarily increased the uptake and utilization of irrigation water, while significantly decreased the uptake and utilization of soil storage water. T2 and T4 with reduced irrigation amounts and optimized irrigation periods helped enhance $\mathrm{WUE}_{\mathrm{S}}$ and $\mathrm{WUE}_{\mathrm{I}}$ demonstrating that enhancing the uptake and utilization of irrigation water and soil storage water could be used as a primary mean to improve WUE.

Grain yields were significantly and positively correlated to $\mathrm{WUE}_{\mathrm{Y}}, \mathrm{WUE}_{\mathrm{P}}, \mathrm{WUE}_{\mathrm{I}}$ and IE $(P<0.05)$, while negative correlation appeared at $\mathrm{WUE}_{\mathrm{S}}$ in two tested years $(P<0.05)$ (Table 5$)$. $\mathrm{WUE}_{\mathrm{Y}}$ was also significantly and positively correlated with $\mathrm{WUE}_{\mathrm{P}}$, WUE and IE $(P<0.05)$, while the correlation between $\mathrm{WUE}_{\mathrm{Y}}$ and WUE $\mathrm{W}_{\mathrm{S}}$ was insignificant in two tested years (Table 5). In addition, there was a remarkable and negative correlation between $\mathrm{WUE}_{S}$, and $\mathrm{WUE}_{\mathrm{P}}, \mathrm{WUE}_{\mathrm{I}}$ as well as IE $(P<0.01)$, whereas there were significant and positive correlations among the WUE WUE $_{\mathrm{I}}$ and IE $(P<0.01)$ (Table 5). These showed that improving WUE, $\mathrm{WUE}_{\mathrm{I}}$, IE and WUE $\mathrm{WU}_{\mathrm{Y}}$ could simultaneously increase $\mathrm{WUE}_{S}$, while the excessive use of soil water would greatly decline wheat grain yields.

\section{Discussion}

With the increased amounts of irrigation water in wheat fields, the total water consumption amounts in all soil layers significantly increase, whereas they quickly decrease in lower soil layer ${ }^{26-28}$. Zheng and his colleagues have found that deep ploughing can increase the total water consumption amounts and increase the consumed amounts of soil storage water ${ }^{29}$. In this experiment, total water consumption amounts in $\mathrm{T} 1$ was significantly higher than both T2 and T4, whereas its proportion of soil storage water was significantly lower than other three managements. The proportions of soil storage water in T3 and T4 were also significantly higher than those of T1 and T2, possibly from deep ploughing (Table 2). These findings are similar to the results of previous studies ${ }^{26-29}$. However, the total water consumption amounts in T3 was significantly higher than T1 and T2, and the proportion of soil storage water in T3 was also higher than T4, probably because deep ploughing and high input of water and fertilizer promoted wheat plants in this management grow vigorously after the jointing stage and wheat plants 
consumed a substantial amounts of water due to transpiration. After we comprehensively evaluated the total water consumption amounts and the water source compositions, the optimized managements of T2 and T4 were characterized with the reduced available soil water at planting and the delayed fertilization and irrigation to the jointing in spring season, resulting in the significantly reduced total water consumption amounts, the increased consumption of precipitation and soil storage water, and the reduced demand for irrigation water (Table 2).

After comparing the amounts of total water consumption, daily water consumption and water consumption coefficient at different growth stages in two successive tested years, we found that amounts of total water consumption and daily water consumption were highest at JTA and ATM stages in all managements, while least at the WTR stage. After wintering stage, the daily water consumption and water consumption coefficient gradually increased in four managements (Table 3). Cui and his colleagues have found that, after anthesis, lower soil layer water was the primary source of supplied water for requirement of wheat plants $s^{30}$. Therefore, improving the utilization of lower soil layer water can ensure a sufficient water supply during the grain filling stage. In this experiment, the effects of water consumption amounts of the different soil layers revealed that the consumed amounts of lower soil layer water in $\mathrm{T} 2$ management were significantly higher than those in $\mathrm{T} 1$, while this parameter in T4 was higher than that in T3 in only 2008-2009. The stages, amounts, and methods of irrigation in T4 need to be optimized (Fig. 2).

Previous studies have shown that added irrigation at the jointing and filling stages could effectively delay flag leaf senescence, and increase the WUE, grain filling rates, and the grain yields ${ }^{31,32}$. However, water deficit during these two stages can lead to a serious decline in the grain yields ${ }^{33}$. Xu and his colleagues have found that reducing the irrigation frequencies before the jointing stage could promote the growth of wheat roots into lower soil layers and increase the absorption of lower soil layer water, resulting in the improved WUE ${ }^{34}$. In addition, irrigation at the jointing stages to the flowering stages of winter wheat has been found to increase the grain yields, harvest index and $\mathrm{WUE}^{35}$. These suggest that irrigation can obviously affect the water utilization of wheat directly during different growth stages. In this study, the grain yields of T2, T3, and T4 were significantly higher than those of T1, and $W U E_{Y}, W^{\prime} E_{p}, W U E_{I}$ and IE in T4 were also higher than those of other three managements (Table 4). WUE $W_{U}, E_{P}, E_{I}$ and IE in T2 were higher compared to T1, similar to the results in some previous studies ${ }^{31-35}$. In this experiment, the grain yields of T3 were highest because of quality-high soil tillage and sowing, enough water and fertilizer supply, and excessive input. Under the above conditions, however, the water use efficiency parameters in T3 were lower than those of the T4 (Table 4). After evaluating on the high water utilization efficiency and grain yields, thus, T4 was considered to be an optimized management with effectively utilizing the precipitation. However, T4 consumed a lower number of total soil storage water amounts, in particular from lower soil layer, than T2 and T3. These suggest that the irrigation water amounts, irrigation methods and mechanism of increasing grain yields and WUE in T4 management need to be optimized and explored.

\section{Conclusions}

Deep ploughing, appropriately reducing amounts of fertilizers and irrigation, nitrogen fertilizer application and adding irrigation at jointing stage in T2 or T4 managements were beneficial methods to improve the absorption and utilization of irrigation and soil storage water in winter wheat, and promote the improvement of grain yields and WUE. These comprehensive managements could help for sustainable development of winter wheat with economizing fertilizers, increasing grain yields, and efficiency-high water utilization.

\section{Materials and Methods}

Experimental set-up. Field experiments. We conducted a field experiment at two successive wheat growth seasons from October 2008 to June 2010 at Xiangyun Town, Wenxian County, Henan Province, China $\left(112^{\circ} 99^{\prime} \mathrm{E}\right.$, $34^{\circ} 92^{\prime} \mathrm{N}$ ). There is a warm temperate semi-humid continental monsoon climate in this region, in which soil is fluvo-aquic clay soil, and other properties of the $0-40 \mathrm{~cm}$ plough-layer soil have been indicated in our previous study $^{36}$ shown in Table 1 . Continuous wheat-maize rotation model was used in these two growth seasons, and all the straws were returned to the field after harvest. A semi-winter bread wheat variety Ping'an 8, characterized with high yield potential, excellent biotic and abiotic tolerance, was used in this study. This variety was developed Henan Ping 'an Seed Industry Co., Ltd., and was released in 2011.

Several combined managements (e.g., tillage, row spacing configuration, water and fertilizer inputs and planting densities) were considered and four treatments were designed as follows: traditional management (T1), optimized management compared with T1 (T2), super high-yield management (T3), and optimized management compared with T3 (T4) (Table 6). For T1, rotary tillage (approximately $15 \mathrm{~cm}$-depth) was performed, whereas rolling was not conducted before sowing. The planting densities of the wheat seeds were $187.5 \mathrm{~kg} \cdot \mathrm{hm}^{-2}$ with 20 $\mathrm{cm}$-width equal row spacing and irrigation was applied after sowing. For T2, T3 and T4, mechanical deep ploughing (over $25 \mathrm{~cm}$-depth) was adopted, soil was harrowed 2-3 times, and rolling was conducted after sowing. Equal row spacing ( $20 \mathrm{~cm}$-width) was adopted in T2, while alternating wide- and narrow row spacing $(15 \mathrm{~cm} \times 23 \mathrm{~cm}$ width) was adopted in T3 and T4. The planting densities of the wheat seeds in T2 were $150 \mathrm{~kg} \cdot \mathrm{hm}^{-2}$, whereas $120 \mathrm{~kg} \cdot \mathrm{hm}^{-2}$ in both T3 and T4. Organic and microelement fertilizers, and phosphate and potassium fertilizers were applied before sowing (Table 6). As the base fertilizers, all nitrogen (N) fertilizers in T1 were applied before sowing one time, while in $\mathrm{T} 2, \mathrm{~T} 3$ and $\mathrm{T} 4,50 \%$ of the $\mathrm{N}$ fertilizers were applied before sowing, and the remaining $50 \%$ were applied at the jointing stages in combined with irrigation. In each wheat growth season, a randomized complete block design and a factorial arrangement of treatments were used with four biological replicates with $50 \mathrm{~m}^{2}$ each. Other managements were the same as local standard wheat practices. In addition, control was established for the whole wheat growth stage without irrigation to calculate the IE, where in each control area was $20 \mathrm{~m}^{2}$, and other inputs were consistent with those of four managements. Sowing was conducted on October 15 for the two wheat growth seasons. Wheat grains were harvested on June 7,2009, and June 11, 2010, respectively. 


\begin{tabular}{|c|c|c|c|c|c|c|c|c|c|}
\hline \multirow[b]{2}{*}{ Managements } & \multicolumn{5}{|c|}{ Amounts of fertilizer application $\left(\mathrm{kg} \cdot \mathrm{hm}^{-2}\right)$} & \multicolumn{4}{|c|}{ Irrigation water stages and amounts $\left(\mathrm{m}^{3} \cdot \mathrm{hm}^{-2}\right)$} \\
\hline & $\mathbf{N}$ & $\mathrm{P}_{2} \mathrm{O}_{5}$ & $\mathrm{~K}_{2} \mathrm{O}$ & $\mathrm{ZnSO}_{4}$ & Organic fertilizer & Soil moisture & Green rose & Jointing & Blossom filling \\
\hline T1 & 225 & 75 & 60 & 0 & 0 & 900 & 900 & 0 & 900 \\
\hline $\mathrm{T} 2$ & 180 & 75 & 60 & 0 & 0 & 600 & 0 & 900 & 900 \\
\hline $\mathrm{T} 3$ & 300 & 150 & 150 & 15 & 3000 & 600 & 0 & 900 & 900 \\
\hline $\mathrm{T} 4$ & 240 & 90 & 90 & 15 & 3000 & \begin{tabular}{|l|l}
600 \\
\end{tabular} & 0 & 600 & 600 \\
\hline
\end{tabular}

Table 6. Irrigation and fertilization management of wheat under different cultivation managements.

Growth conditions. There were some differences in climate conditions in two wheat growth seasons (Table 1). From the beginning of October to the end of January in 2008-2009, precipitation was only $32 \mathrm{~mm}, 44.76 \mathrm{~mm}$ less than the average precipitation in normal years. Especially from December 2008 to January 2009, there was merely $0.2 \mathrm{~mm}$ precipitation, $15.48 \mathrm{~mm}$ less than the average precipitation in normal years. Thus, there occurred a serious drought stress during the early growth stages in this wheat planting season. In 2009-2010, there occurred severe low temperature stress ( 0.87 lower than average values in previous successive 45 wheat growth seasons, from 1962-2006) in winter and spring seasons. This stress occurred early and lasted for a long stage (from the beginning of November to the end of April) in this season (Table 1). Especially in November this year, average temperature was only $4.90^{\circ} \mathrm{C}, 3.22^{\circ} \mathrm{C}$ lower than average values. Throughout the growth stage, the total accumulated temperature was $106.90^{\circ} \mathrm{C}$ lower than average values. The duration of sunshine decreased by $268.0 \mathrm{~h}$, primarily because of a $117.5 \mathrm{~h}$ decrease in February and March 2010.

Measurements. Soil water. Soil samples were randomly drilled at three points in each plot before sowing and at the main wheat growth stages. Each $20 \mathrm{~cm}$-depth soil was considered as one layer, and $1 \mathrm{~m}$-depth soil was sampled for 3 times at each plot. Then the sampled soil layers were mixed in one plot and immediately placed in an aluminium box. For the determination of the soil water content, wet soil samples were first weighed and baked in a $110^{\circ} \mathrm{C}$ oven for $10-12 \mathrm{~h}$ to constant weights and then weighed again. Equation (1) was used to calculate the soil quality water content.

$$
\theta=\frac{W 1-W 2}{W 2} \times 100
$$

$\theta, W 1$, and $W 2$ represent the soil water content (\%), the wet and dry soil weights (g), respectively.

Total water consumption and soil storage water. According to previous study ${ }^{32}$, total soil water consumption was determined with Equation (2):

$$
\Delta S=10 \Sigma \gamma_{i} H_{i}\left(\theta_{i l}-\theta_{i 2}\right) \quad i(1, n)
$$

$\Delta \mathrm{S}, i, n, \gamma_{i}, H i, \theta_{i}$, and $\theta_{\mathrm{i} 2}$ represent the soil water storage consumption (mm), the number of solum, total soil layers, soil dry bulk density of layer $i\left(\mathrm{~g} . \mathrm{cm}^{-3}\right)$, the thickness of the soil $(\mathrm{cm})$, the soil water content at the beginning of layer $i$, and the soil moisture at the end of layer $i$, respectively. Values are expressed as percentage (\%) of the dry soil weight.

Soil storage water was calculated based on the method of Liu and his colleagues ${ }^{37}$, and this parameter was determined using Equation (3):

$$
E T_{1-2}=10 \sum_{i=1}^{n} \gamma_{i} \mathrm{H}_{i}\left(\theta_{i 1}-\theta_{i 2}\right)+I+\mathrm{P}+\mathrm{K} \quad \mathrm{i}(1, \mathrm{n})
$$

$E T_{1-2}$ is water consumption amounts at stage $(\mathrm{mm})$, and $i, \mathrm{n}, \gamma_{\mathrm{i}}, \mathrm{H}_{\mathrm{i}}, \theta_{\mathrm{i} 1}, \theta_{\mathrm{i} 2}$ are the same as those in Equation (2). $I, P$, and $K$ represent the total irrigation amounts $(\mathrm{mm})$, precipitation $(\mathrm{mm})$, and increment of groundwater $(\mathrm{mm})$, respectively. When the depth of groundwater is over $2.5 \mathrm{~m}$, the $\mathrm{K}$ value can be neglected. In this study. The depth is under $5 \mathrm{~m}$, and the $\mathrm{K}$ can be regarded as 0 .

WUE. $\quad \mathrm{WUE}_{\mathrm{Y}}, \mathrm{WUE}_{\mathrm{I}}, \mathrm{WUE}_{\mathrm{P}}, \mathrm{WUE}$, and IE were determined using Equations (4-8), respectively.

$$
\begin{gathered}
W U E_{Y}=Y / E T \\
W U E_{I}=Y / I \\
W U E_{P}=Y / P \\
W U E_{S}=Y / \Delta S \\
I E=\left(Y_{i}-Y_{n i}\right) / I
\end{gathered}
$$


Units of $\mathrm{WUE}_{\mathrm{Y}}, \mathrm{WUE}_{\mathrm{I}}, \mathrm{WUE}_{\mathrm{p}}$ and $\mathrm{WUE}_{\mathrm{S}}$ are $\mathrm{kg} \cdot \mathrm{hm}^{-2} \cdot \mathrm{mm}^{-1} ; Y, P, \Delta S, E T, I, Y_{i}$, and $Y_{n i}$ represent the yields $\left(\mathrm{kg} \cdot \mathrm{hm}^{-2}\right)$, precipitation $(\mathrm{mm})$, amounts of the soil water consumption $(\mathrm{mm})$, amounts of total water consumption $(\mathrm{mm})$, irrigation amounts, grain yields in irrigation management $\left(\mathrm{kg} \cdot \mathrm{hm}^{-2}\right)$, and yields in non-irrigation management $\left(\mathrm{kg} \cdot \mathrm{hm}^{-2}\right)$.

Grain yields and components. At maturity stage, wheat plants in $10 \mathrm{~m}^{2}$ area were harvested in each experimental plot, and the harvested samples were threshed and dried to calculate the grain yields $\left(\mathrm{kg} \cdot \mathrm{hm}^{-1}\right)$.

Statistical analysis. The experimental data were evaluated using analysis of variance (ANOVA) and correlation analysis with SPSS 16.0, and multiple comparisons were conducted for significance using the least significant difference (LSD) at 0.05 and 0.01 levels.

\section{References}

1. Ru, Z. G. et al. High-Yield potential and effective ways of wheat in Yellow \& Huai River valley facultative winter wheat region. Scientia Agricultura Sinica. 48(17), 3388-3393 (in Chinese with English abstract) (2015).

2. Yu, Z.W. Special Crop Cultivation. Beijing: China Agriculture Press. (in Chinese with English abstract) (2003).

3. Fang, Q. X. et al. Water resources and water use efficiency in the North China Plain: Current status and agronomic management options. Agr Water Manage. 97, 1102-1116 (2010).

4. Shao, L. et al. Effects of irrigation frequency under limited irrigation on root water uptake, yield and water use efficiency of winter wheat. Irrig Drain. 58(4), 393-405 (2009).

5. Zhang, J. et al. Effects of different planting patterns on water use and yield performance of winter wheat in the Huang-Huai-Hai plain of China. Agr Water Manage. 92, 41-47 (2007).

6. Li, Q. et al. Winter wheat grain yield and water use efficiency in wide-precision planting pattren under deficit irrigation in North China Plain. Agr Water Manage. 153, 71-76 (2015).

7. Kang, S., Zhang, L., Liang, Y. \& Dawes, W. Effects of limited irrigation on yield and water use efficiency of winter wheat on the Loess Plateau of China. Agr Syst. 78, 355-367 (2003).

8. Ali, M. H., Hoque, M. R., Hassan, A. A. \& Khair, A. Effects of deficit irrigation on yield, water productivity, and economic returns of wheat. Agr Water Manage. 92, 151-161 (2007).

9. Liu, H., Li, F. \& Jia, Y. Effects of shoot removal and soil water content on root respiration of spring wheat and soybean. Environ Exp Bot. 56, 28-35 (2006).

10. Wei, H. H. et al. Meta analysis on impact of no-tillage and subsoiling tillage on spring maize and winter wheat yield and water use efficiency on the Loess Plateau. Scientia Agricultura Sinica. 50(3), 461-473 (in Chinese with English abstract) (2017).

11. Drewry, J. J., Lowe, J. A. H. \& Paton, R. J. Effect of subsoiling on soil physical properties and pasture production on a pallic soil in southland, New Zealand. New Zeal J Agr Res. 43(2), 269-277 (2000).

12. Mohanty, M. et al. Water transmission characteristics of a vertisol and water use efficiency of rainfed soybean (Glycine max (L.) Merr.) under subsoiling and manuring. Soil Till Res. 93, 420-428 (2007).

13. Zhang, Y. L., Yu, Z.W., Zheng, C. Y. \& Gu, S. B. Effects of different irrigation managements on water consumption characteristics and grain starch components accumulation in strong gluten wheat Jimai 20. Scientia Agricultura Sinica. 42(12), 4218-4227 (in Chinese with English abstract) (2009).

14. Xiao, J. F., Liu, Z. D., Liu, Z. G. \& Nan, J. Q. Effects of different irrigation times on growth and water use efficiency of summer maize. Journal of Henan Agricultural Sciences. 40(2), 36-40 (2011). (in Chinese with English abstract).

15. Dang, J. Y., Zhang, D. Y., Pei, X. X. \& Yang, Z. G. Moisture and temperature effects of different tillage and film-mulching techniques for spring maize in the gully region of the Loess Plateau. Chinese Journal of Eco-Agriculture. 14(3), 75-77 (in Chinese with English abstract) (2006).

16. Samuilov, F. D. \& Mukhitov, L. A. Water regime and water consumption of spring soft wheat varieties of different ecological groups under contrasting water availability conditions. Russian Agricultural Sciences. 38(5-6), 353-357 (2012).

17. Wang, B. et al. Grain Yield and Water Use Efficiency in Extremely-Late Sown Winter Wheat Cultivars under Two Irrigation Regimes in the North China Plain. Plos One. 11(4), e0153695 (2016).

18. Sang, X., Wang, D. \& Lin, X. Effects of tillage practices on water consumption characteristics and grain yield of winter wheat under different soil moisture conditions. Soil Till Res. 163, 185-194 (2016).

19. Gupta, N. et al. Effects of tillage and mulch on the growth, yield and irrigation water productivity of a dry seeded rice-wheat cropping system in north-west india. Field Crop Res. 196, 219-236 (2016).

20. Ghane, E., Mostafazadeh-Fard, B., Feizi, M. \& Landi, E. Effect of Water Quality and Different Planting Methods on Wheat Yield. Commun Soil Sci Plan. 42(4), 369-380 (2011).

21. Li, Q. Q., Zhou, X. B., Chen, Y. H. \& Yu, S. L. Water consumption characteristics of winter wheat grown using different planting patterns and deficit irrigation regime. Agr Water Manage. 105, 8-12 (2012).

22. Wang, Y. et al. Reduced irrigation increases the water use efficiency and productivity of winter wheat-summer maize rotation on the North China Plain. Sci Total Environ. 618, 112-120 (2018).

23. Meng, W. W. et al. Effects of supplemental irrigation on water consumption characteristics and grain yield in different wheat cultivars. Chil J Agr Res. 75(2), 216-223 (2015).

24. Wang, C. Y. et al. Effects of different irrigation and nitrogen regimes on root growth and its correlation with above-ground plant parts in high-yielding wheat under field conditions. Field Crop Res. 165, 138-149 (2014).

25. Zhang, Y. et al. Nitrogen fertigation effect on photosynthesis, grain yield and water use efficiency of winter wheat. Agr Water Manage. 179, 277-287 (2017).

26. Musick, J. T., Jones, O. R., Stewart, B. A. \& Dusek, D. A. Water-yield relationships for irrigated and dry land wheat in the U.S. southern plains. Agron J. 86(6), 980-986 (1994).

27. Oweis, T. et al. Water use efficiency of rainfed and irrigated bread wheat in a Mediterranean environment. Semigroup Forum. 92(2), 231-238 (2000).

28. Sun, H. Y. et al. Effects of irrigation on water balance, yield and WUE of winter wheat in the North China Plain. Agr Water Manage. 85(1-2), 211-218 (2006).

29. Zheng, C. Y. et al. Effects of tillage practices on water consumption, water use efifciency and grain yield in wheat field. J Integr Agr. 13(11), 2378-2388 (2014).

30. Cui, H. H. et al. Simulation study on optimal dept of soil storage capacity for rained wheat on loess plateau. J Soil Water Conserv. 17(4), 110-112 (in Chinese with English abstract) (2003).

31. Li, Q. Q. et al. Root growth, available soil water, and water-use efficiency of winter wheat under different irrigation regimes applied at different growth stages in North China. Agr Water Manage. 97(10), 1676-1682 (2010).

32. Guo, Z., Shi, Y., Yu, Z. \& Zhang, Y. Supplemental irrigation affected flag leaves senescence post-anthesis and grain yield of winter wheat in the Huang-Huai-Hai Plain of China. Field Crop Res. 180, 100-109 (2015). 
33. Tari, A. F. The effects of different deficit irrigation strategies on yield, quality, and water-use efficiencies of wheat under semi-arid conditions. Agr Water Manage. 167, 1-10 (2016).

34. Xu, C. L. et al. Limited-irrigation improves water use efficiency and soil reservoir capacity through regulating root and canopy growth of winter wheat. Field Crop Res. 196, 268-275 (2016).

35. Xue, Q. et al. Root growth and water uptake in winter wheat under deficit irrigation. Plant Soil. 257(1), 151-161 (2003).

36. Wang, Y. H. et al. Effects of cultivation patterns on winter wheat root growth parameters and grain yield. Field Crop Res. 156, 208-218 (2014).

37. Liu, Z. J., Li, B. P., Li, Y. H. \& Cui, Y. L. Research on the water use efficiency and optimal irrigation schedule of the winter wheat. Transactions of the CSAE.y 20(4), 58-63 (2004). (in Chinese with English abstract).

\section{Acknowledgements}

This study was funded by the National Natural Science Foundation of China (NSFC, 31471439), China Agricultural Research System (CARS-03) and Major Science and Technology Research Program of Henan (141100110300). We greatly appreciate Henan Pingan Seed Co. LTD. for their substantial support of this study.

\section{Author Contributions}

T.G. and Y.W. designed the research; H.L. wrote the main manuscript text; Y.H. and J.W. analyzed the data; Z.W. and M.X. collected the data; G.K. and W.F. contributed to data interpretation; F.G. contributed to the revised manuscript. All authors discussed the results and commented on the manuscript at all stages.

\section{Additional Information \\ Competing Interests: The authors declare no competing interests.}

Publisher's note: Springer Nature remains neutral with regard to jurisdictional claims in published maps and institutional affiliations.

(c) (i) Open Access This article is licensed under a Creative Commons Attribution 4.0 International License, which permits use, sharing, adaptation, distribution and reproduction in any medium or format, as long as you give appropriate credit to the original author(s) and the source, provide a link to the Creative Commons license, and indicate if changes were made. The images or other third party material in this article are included in the article's Creative Commons license, unless indicated otherwise in a credit line to the material. If material is not included in the article's Creative Commons license and your intended use is not permitted by statutory regulation or exceeds the permitted use, you will need to obtain permission directly from the copyright holder. To view a copy of this license, visit http://creativecommons.org/licenses/by/4.0/.

(c) The Author(s) 2019 